\title{
IMPORTANCE OF EUROPEAN COMMISSION'S NEW INITIATIVES IN ROAD TRANSPORT FOR COMPETITIVENESS OF SERVICES PROVIDED BY POLISH HAULIERS
}

\author{
ALEKSANDRA KOŹLAK \\ University of Gdansk, POLAND \\ e-mail: a.kozlak@ug.edu.pl
}

RECEIVED

ACCEPTED

JEL

CLASSIFICATION

KEYWORDS

ABSTRACT
26 July 2017

15 December 2017

$\mathrm{R} 40, \mathrm{R} 41, \mathrm{R} 48$

road transport, competitiveness, access to market, regulation

Road freight transport is the main inland transport mode in the EU. International transport is fully open to competition and it is only national transport that is still subject to some restrictions. Access to the road haulage market and certain social and safety conditions (such as hours of driving) are regulated at the EU level. Taking into account changes on the market and the current situation the European Commission has decided to renew the most important regulations. The main research problem in this paper is how these new regulations will influence competitiveness of Polish hauliers. The article analyses the current competitiveness of Polish hauliers and the impact of the EC's proposals on their activities. Methodology of the research includes analysis of the scientific literature, documents of European Commission and statistical data analysis.

Research findings show that Polish hauliers increased their performance and share in the European road haulage market last years. The most important factor of the competitiveness on the road transport market is the price as the quality of services is rather similar. Polish companies have competitive advantage on account of lower costs, mainly the cost of fuel and driver wages. The changes in regulations proposed in the "Europe on the Move" road package will significantly increase costs of Polish enterprises and thus decrease their competitiveness.

\section{Introduction}

The international transport market encompasses a diverse space in geographical, economic, organizational and technical terms which creates diverse competitive conditions for hauliers from different countries. These differences are considerably smaller between countries that have been European Union members for a long time and the Central and Eastern Europe (CEE) countries that joined the Community in 2004 and later. 
The EU has already achieved a relatively high level of harmonization of the conditions of competition, which is a result of many years of work of the legislative bodies of the Community. It has aligned the law to the needs arising from the economic integration and liberalization of transport markets. The freedom to provide services is a fundamental principle of the common transport policy. It requires that all hauliers from the member states are guaranteed access to international transport markets without discrimination depending on their nationality or place of domicile. It was therefore necessary to harmonize the national rules concerning the technical standards for vehicles, the rules of haulier licensing, the freedom of establishing enterprises, the social regulations or the tax systems in order to shift from the quantitative to qualitative market regulatory framework.

The work recently undertaken by the European Commission has been triggered by major changes in the market share of hauliers from individual countries (an increased share of hauliers from the Central and Eastern Europe) and by introduction of restrictive measures by countries that wish to impede access to their internal markets justifying it by social reasons. The European Commission is working on preparing amendments to selected legislative acts, which mainly concern access to the haulier's profession and to the market in respect of selected social regulations including remuneration of posted workers and the road toll systems.

The main research problem in this paper is how these new regulations will influence competitiveness of Polish hauliers. The aim of the article is to assess the current competitive position of Polish hauliers on the European freight market and to determine the impact of the changes proposed by the European Commission in the "Europe on the Move" road package on their competitiveness. Results of this study can be useful for the purposes of transport policy. Methodology of the research includes analysis of the scientific literature, documents of European Commission and statistical data analysis. The competitiveness of carriers from different countries is assessed on the basis of the rate of changes in the freight volume and the transport performance as well as the share in European market.

\section{Conception of enterprises' competitiveness}

Competitiveness as an economic category, in the most general terms, is defined as the ability to succeed in economic competition. This term is derived from a sphere of microeconomics that investigates the behaviour of economic entities operating in the conditions of market economy that seek for ways to gain and retain advantage over other market participants performing similar activities. It is important to emphasize the difference between the concepts of competitiveness and competition, since competitiveness is a feature (characteristic) of specific entities, while the notion of competition determines the processes taking place in the market in which entities compete (Koźlak, 2007).

The concept of competitiveness is one of the basic terms of modern economics, nonetheless, in the literature it is defined differently and interpreted in different ways which results from non-uniform views and various value systems of the authors of specific definitions. For example, neoclassical economics explains competitiveness within the framework of the microeconomic price theory in a perfectly competitive market, while in the theory of marketing, competition is considered from the consumer's point of view and preferences (Chmielak, 2004). The wide overview of concepts, definitions and measures of competitiveness can be find in the article of Siudek and Zawojska (2014).

The vast majority of the definitions of competitiveness refer to the notion of ability: "competitiveness is the ability to..." (Flejterski, 1984; Buckley, Pass, Prescott, 1988; Krugmann, 1990; Porter 1990), however, it is fairly difficult to measure and evaluate this ability, which in practice leads to an assessment of the level of ex-post competitiveness by observing the results of competition. For example, Flejterski (1984) has defined competitiveness as the ability to 
design, manufacture and market products the prices, quality, and other attributes of which are more attractive than those offered by competitors.

Competitiveness can be looked at three different but interrelated levels: country, industry and firm level. Many of the definitions are universal, applicable at every level of competition, which means that they can refer to an enterprise, a region, a country, or even a group of co-operating countries. These include the OECD (1992) definition, one of the most well-known and most often quoted ones, whereby the essence of competitiveness is the ability of companies, sectors, regions, nations or transnational groups to compete, i.e. to increase their market share and ability to sustainably maintain a high rate of return on the employed factors of production and a high level of employment (Stankiewicz, 2002).

Defining competitiveness is complicated by the fact that the notion of competitiveness may include both a dynamic element that determines the factors that make up a competitor's ability to compete and a static one that determines the effect of that ability at a given moment. Therefore, it is possible to speak about a competitive ability and a competitive position whereby three types of definitions can be distinguished (Radło, 2008):

1. Competitive position definitions that relate to the results achieved by the entity, including economic performance and market share. They focus on assessing the achieved competitive position.

2. Competitive ability definitions that focus on evaluating the sources of competitiveness of the entity that affect future competitive positions such as the size and structure of resources or the efficiency of their use. These definitions assess an entity's ability to cope with competition, i.e. its competitive ability.

3. Mixed competitive ability and competitive position definitions which combine both the above approaches to the assessment of competitiveness. Definitions of this type are of a most complete nature, as they take into account the interaction that occurs between the achieved level of competitiveness and the set of its determinants.

Primary sources of competitiveness are born in the process of development of enterprises. These sources can be categorized under 'asset', 'processes' and 'performance' on spectrum of strategic and operational levels (Ajitabh, Momaya, 2004). However, it is also the economic, political and social environment of the region and the country that can foster or not the international competitiveness of enterprises and certain sectors of the economy (Pierścionek, 2006).

\section{Competitiveness of Polish road hauliers on European market}

The entry of Poland into the European Union and the liberalization of restrictions on access to the transport market, initially in international transport, and then in cabotage carriage (i.e. carriage of cargo in a country other than the country in which the vehicle is registered) as well, has created new prospects of development for Polish road transport companies, but it has also created conditions of international competition different than before. The number of competing entities from different countries has increased significantly, and the factors influencing the competitiveness of enterprises have become more diversified.

The competitiveness of transport services provided by carriers from different countries can be assessed on the basis of the rate of changes in the freight volume and the transport performance as well as in the share of hauliers from individual countries in the freight turnover on the European market. Firstly, the rate of changes in the transport performance was analyzed compared to 2000 , which was assumed as the base year. The rate of changes in the transport performance of all EU-28 hauliers and Polish hauliers was compared (Figure 1). 


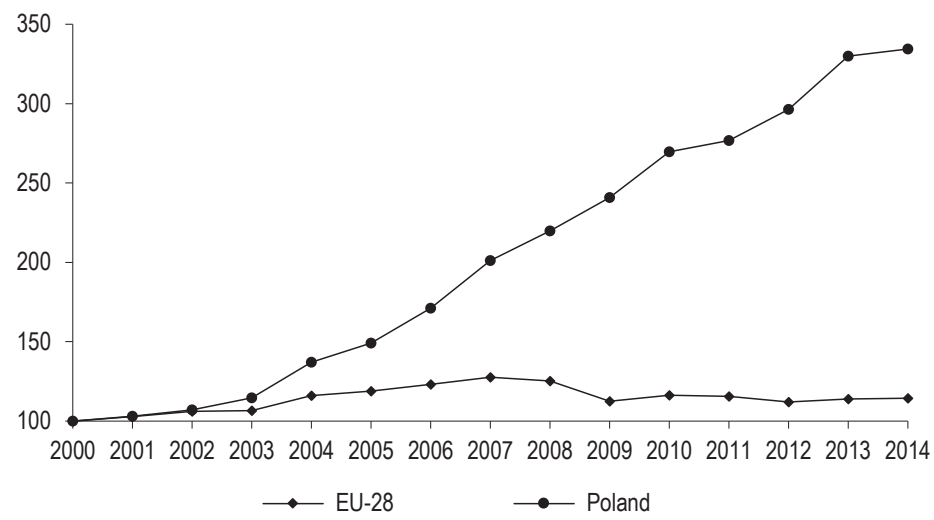

Figure 1. Rate changes in transport performance in EU-28 and in Poland in 2000-2014 $(2000=100)$

Source: own elaboration on base of data European Commission (2016).

Figure 1 shows that a significant increase in the transport performance in the European Union was noted after accepting new countries to the group in 2004, and then, following the global economic recession, the freight volume decreased in 2008-2009. In the following years, the transport performance volume was at a similar level in the range of 1,693-1,755 billion tonne-kilometres (European Commission, 2016). And the transport performance of Polish hauliers was steadily increasing, even in those years where a decline in the EU was noted. In the years 2000-2014, the transport performance of Polish hauliers increased by almost $235 \%$, which proves their high competitiveness and constant development. The largest portion of the increase in the transport performance of Polish hauliers is accounted for by international transport, both in the service of the Polish foreign trade as well as the foreign and domestic trade of third countries.

Polish hauliers have been successful on the European market, and the growth in their transport performance is significantly better than the performance of hauliers from other countries. This was confirmed by further analysis of competitiveness, which consisted in comparing the volume of change in the transport performance of hauliers from all member countries in the period 2000-2014. Both the change in the transport performance volume in natural units (tkm) as well as in per cent was considered to show the rate of change (Figure 2).

In the analysed period, the greatest increase in the transport performance was noted by the Polish hauliers ( 175.9 billion $\mathrm{tkm}$ ) and it was four times more than achieved by the Spanish hauliers who took the second place in this regard and six times more than the German carriers. A significant growth rate in the transport performance was seen with the hauliers from Bulgaria, Lithuania and Croatia, however, the values of this increase were not higher than 22 billion tkm. The expansion of Polish hauliers in the European market has led to the takeover of a large portion of the freight operated so far by hauliers from other countries. The greatest losers in this respect were hauliers from Italy, France, the United Kingdom and Belgium.

Due to the above mentioned changes in the transport performance volume, the share of hauliers from individual countries in the market has also changed. The Germans managed to maintain the largest market share $(18 \%)$, while Italian, French and British hauliers were overtaken by Polish hauliers taking the second position with a share of $14.5 \%$, followed by Spanish carriers with a share of $11.3 \%$. Subsequent places were taken by French 
$(9.6 \%)$ and British (8.3\%) hauliers. The carriers of the five mentioned countries with the highest market share account for $61.7 \%$ of the transport performance in all the EU member countries.

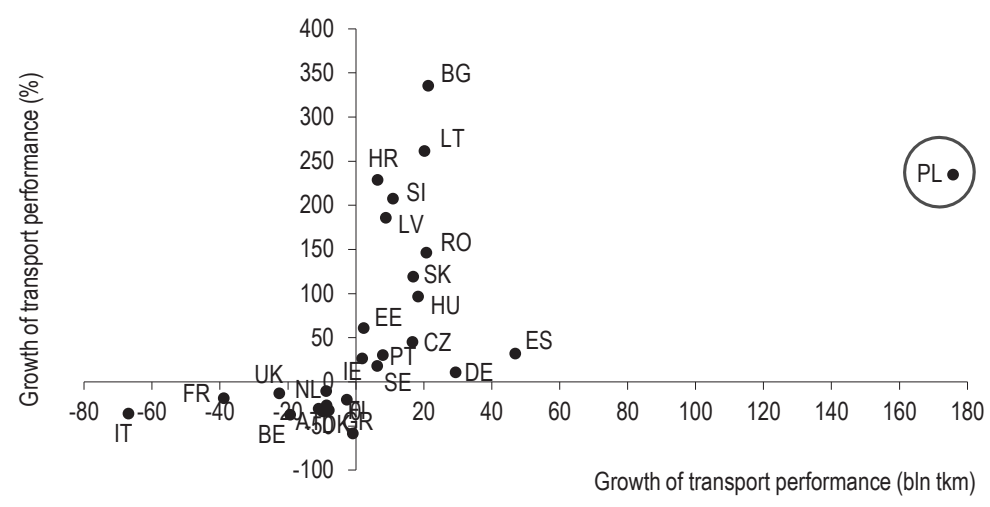

Figure 2. Change of haulage in EU countries in 2000-2014 (in billion tkm and in \%)

Source: own elaboration on base of data European Commission (2016).

The competitive position achieved in the transport market is a result of internal (depending on the haulier) and external (resulting from the socio-economic specifics of the member states' policy) competitive factors (Koźlak, 2007). According to Burnewicz (2017), factors of the highest significance for competitive ability of enterprises in road transport sector are: costs and prices of transport services, quality of services, flexibility and adjustment to client's needs, organisational potential of the companies, human resources, fleet of transport vehicles and modern technologies. Nevertheless, the most important competitive factor in the road freight transport is the price of the service, as the quality of service is generally at a similar level (Langvinienè, Sližienè, 2012).

The price level depends on the cost of providing the service and the applied profit margin. The basic components of road transport costs are wages and payroll deductions, purchase costs of consumables (mainly fuels), depreciation, taxes and fees. Central and Eastern European countries are gaining competitive advantage mainly due to the relatively low labour costs and lower fuel prices, to some extent. On the other hand, most of the old member states are characterized by a higher level of technology, innovation and better productivity. The cargo volume is also influenced by the size of the internal market, which is particularly visible in the case of Germany and Spain. Eurostat data shows that foreign hauliers have taken over only a small portion of the national freight volume of a given country. The share of foreign hauliers in national transport varies from $0.5 \%$ in Croatia to $10 \%$ in Belgium, while the EU-28 average is approx. 3\% (European Commission, 2017a).

\section{European Commission's new initiatives in road transport and their impact on Polish hauliers}

Since the beginning of the functioning of the common market of the European Union (formerly the EEC), road transport has been the subject of interest of the authorities responsible for the transport policy and it is for this transport sector that the greatest number of legal acts have been issued. They have concerned both the harmonization of different types of standards as well as access to specific fragmentary markets. The road transport 
is used for the largest number of transport operations and this branch is of fundamental importance for the functioning of the whole industry.

Although the EU regulations are regularly amended and better adapted to the market realities, in some countries they do not sufficiently protect the market from the competition from Central and Eastern European hauliers. Taking advantage of the ambiguity of some EU regulations or the fact that certain issues have not been regulated, these countries introduce their own solutions to restrict through administrative or legal measures the possibility for foreign hauliers to provide transport services. These solutions restrict access to cabotage directly or indirectly through increased costs of providing services (the requirement to use minimum wages in the country of service), complicating the administrative procedures and imposing very high penalties for oversight and breach of regulations.

Monitoring of the European road transport market and the occurrence of various negative phenomena on this market (from the point of view of some or a whole group of countries) is the reason why the European Commission from time to time takes initiatives to make changes in the existing laws or to adopt new ones. It does not always find justification for the purposes of improving the functioning of the market, increasing efficiency and reducing external costs. Unfortunately, this is often a result of pressure from some stakeholders operating in the market.

In late May 2017 the European Commission presented the so called "Europe on Move" road package including a proposal to amend the most important legal acts related to the road transport (European Commission, 2017b). These changes concern three areas: (1) the functioning of the internal market; (2) social legislation; (3) road tolls. As the regulations of the third group focus on aspects of unifying the electronic road toll platform, they will not be considered hereinafter. However, the competitiveness of Polish carriers will be affected by the proposed changes in the functioning of the market and social regulations.

An important element of the "road package" are the regulations on cabotage. Currently, cabotage is limited to 3 operations and to 7 days. If the proposed amendments enter into force, the regulation limiting the number of cabotage routes will cease to apply. The only limit for cabotage will be a 5 day time limit (European Commission, 2017d). In practice, this would liberalize the cabotage rules, since it would be possible to operate on short routes and make several times more operations than before. This solution should be considered as beneficial from the point of view of Polish hauliers as it would reduce the number of the so called empty routes and it would improve efficiency. Nonetheless, the reason for the dissatisfaction of Polish transport companies is the proposal to shorten the cabotage period from 7 to 5 days.

Another important issue in terms of market functioning is the professionalization of the transport market for vehicles below 3.5 tonnes DMC. Although the introduction of tachographs has been abandoned, nonetheless, certain provisions, e.g. those related to the establishment of transport enterprises or the requirement to obtain Community licenses will apply to enterprises that use such vehicles. However, no specific drafts of the new legislation have been presented yet (European Commission, 2017b).

The social regulations include provisions related to the remuneration of employees and the working time of drivers. The proposed regulation on posting workers to another country assumes that drivers will be considered as posted already after 3 days, and in the situation of cabotage operations (the point of loading and unloading is within one country) from the first day already. The problem is that the posting of workers will not only mean the requirement to pay the host country's minimum wages (as was the case under the national laws of e.g. Germany or 
France), but also to comply with a whole range of other national regulations such as social allowances or holiday leave regulations (European Commission, 2017c).

Changes in the rules of posting workers will be especially painful for Polish hauliers, as the wages of drivers will increase, and in this way Polish companies will lose their current competitive advantage. Enterprises may try to avoid becoming subject to this regulation by rotating drivers on specific routes, but this in turn would force an increase in employment and possibly the purchase of additional vehicles. Such "procedure" can be problematic also due to the fact that currently there are not too many drivers with licenses to drive heavy vehicle systems. The increase in costs may slightly limit the reduction of bureaucracy and requirements for transport companies to keep and provide adequate documentation to the authorities of the countries that have already introduced the provisions relating to the posting of road transport workers. The EC plans to standardize the posting system in the whole EU by introducing an electronic platform, removing the obligation to have a representation in each country to which the employee is posted and authorize the storage of payroll records in the electronic form only (OCRK, 2017).

The proposed changes concerning the working time are aimed at making the working time schedule more flexible by allowing the driver to receive two subsequent short-term weekly rests within a 4-week period, retaining of course the applicable rules of compensation. On the other hand, the European Commission believes that drivers should have the right to rest in appropriate conditions, which involves the ban on having the regular weekly rests lasting over 45 hours in the vehicle cab. Drivers should rest at a place of accommodation equipped with sleeping and sanitary facilities (European Commission, 2017e). As a result, Polish transport companies will incur additional accommodation costs for drivers who have slept in vehicle cabs so far or they will have to plan routes in such a way that drivers should arrive for a regular weekly rest at home. The latter situation will also be more beneficial for drivers as it will allow them to spend more time with their families. The growing cost of providing drivers with accommodation outside the vehicle will affect carriers from countries located peripherally in relation to the largest transport markets, i.e. mainly from Central and Eastern Europe.

\section{Conclusions}

Many Polish road haulage enterprises are implementing strategies of expansion on international markets and the position achieved by them in Europe shows that they are competitive. The analysis of the competitive ability of enterprises from different countries has shown that the increase in the transport performance volume of Polish hauliers was several times higher than in other countries, and hauliers from some countries noted even a decrease in the freight volumes. The main factor of competitiveness has turned out to be lower labour costs.

The takeover of a significant part of the market by hauliers from Central and Eastern Europe has raised objections in countries with higher costs of providing services. There is an opinion that taking advantage of large differences in labour costs is inconsistent with fair competition and that wages should be at the same level as in the country where the service is provided. Unfortunately, the European Commission has agreed with this opinion and if the regulation is adopted in the proposed form, the costs will significantly increase in Polish enterprises and they will have to raise prices. The widespread rise in prices of transport services in Europe will translate into an increase in the prices of transported goods, and as a result of an increase in the cost of transport services, the competitiveness of the European Union as a whole in the world market may decline.

The proposals of changes presented in the "EC road transport package" designate a new direction for the functioning of the European road transport market and will be implemented gradually, after being finally formed 
following consultations and negotiations. Negotiations will not be easy as neither the EU-15 nor the Central and Eastern European countries are satisfied, the former with the liberalization of cabotage in particular, and the latter believing that most of the planned changes will increase the costs of the provided services and decrease their competitiveness.

\section{References}

Ajitabh, A., Momaya, K.S. (2004), Competitiveness of firms: review of theory, frameworks and models. Singapore Management Review, 1 (26), 45-61.

Buckley, P.J., Pass, C.L., Prescott, K. (1988). Measures of international competitiveness: a critical survey. Journal of Marketing Management, 4 (2), 175-200.

Burnewicz, J. (2017). The competitiveness of Polish road transport on the European market, ResearchGate. Retrieved from: https:/l www.researchgate.net/publication/315656322 (12.03.2018).

Chmielak, A. (2004). Próba interpretacji konkurencyjności systemowej. In: J. Szabłowski (ed.), Strategie konkurencji przedsiębiorstw wybrane zagadnienia. Białystok: Wyższa Szkoła Finansów i Zarządzania w Białymstoku.

European Commission (2016). EU transport in figures 2016. Luxembourg: DG for Mobility and Transport.

European Commission (2017a). An Overview of the EU Road Transport Market in 2015. Luxembourg: DG for Mobility and Transport.

European Commission (2017b). Europe on the Move: Commission takes action for clean, competitive and connected mobility. Retrieved from: https://ec.europa.eu/transport/modes/road/news/2017-05-31-europe-on-the-move_en (30.06.2017).

European Commission (2017c). Proposal for a Directive of the European Parliament and of the Council amending Directive 2006/22/EC as regards enforcement requirements and laying down specific rules with respect to Directive 96/71/EC and Directive 2014/67/ EU for posting drivers in the road transport sector. $\operatorname{COM}(2017) 278$ final.

European Commission (2017d). Proposal for a Regulation of the European Parliament and of the Council amending Regulation (EC) No 1071/2009 and Regulation (EC) No 1072/2009 with a view to adapting them to developments in the sector. COM/2017/0281 final.

European Commission (2017e). Proposal for a Regulation of the European Parliament and of the Council amending Regulation (EC) No 561/2006 as regards on minimum requirements on maximum daily and weekly driving times, minimum breaks and daily and weekly rest periods and Regulation (EU) 165/2014 as regards positioning by means of tachographs. COM/2017/0277 final.

Flejterski, S. (1984). Istota i mierzenie konkurencyjności międzynarodowej. Gospodarka Planowa, 9.

Koźlak, A. (2007). Ekonomika transportu. Teoria i praktyka gospodarcza. Gdańsk: Wydawnictwo Uniwersytetu Gdańskiego.

Krugman, P. (1990). The age of diminished expectations. Cambridge: The MIT Press.

Langvinienè, N., Sližienè, G. (2012). Factors for competitiveness in the freight transport services market: case of Lithuania. Economics and Management, 1 (17), 264-271.

OCRK (2017). Zasadnicze zmiany w europejskim transporcie - szczegóły pakietu drogowego. Bielsko-Biała: Ogólnopolskie Centrum Rozliczania Kierowców. Retrieved from: http://www.ocrk.pl/aktualnosci/szczegoly-pakietu-drogowego (30.06.2017).

OECD (1992). Technology and the economy: the key relationships. Paris: The Organisation for Economic Co-operation and Development.

Pierścionek, Z (2006). Strategie konkurencji i rozwoju przedsiębiorstwa. Warszawa: Wydawnictwo Naukowe PWN.

Porter, M.E. (1990). The competitive advantage of nations. New York: The Free Press.

Radło, M.J. (2008). Międzynarodowa konkurencyjność gospodarki. Uwagi na temat definicji, czynników i miar. Warszawa: Szkoła Główna Handlowa, Instytut Gospodarki Światowej. Retrieved from: http://www.radlo.org/mkg.pdf (28.02.2015).

Siudek, T., Zawojska, A. (2014). Competitiveness in the economic concepts. Theories and empirical research. Acta Scientiarum Polonorum. Oeconomia, 1 (13), 91-108.

Stankiewicz, M. (2002). Konkurencyjność przedsiębiorstwa. Budowanie konkurencyjności przedsiębiorstwa w warunkach globalizacji. Toruń: TNOiK Dom Organizatora.

Cite this article as: Koźlak, A. (2018). Importance of European Commission's new initiatives in road transport for competitiveness of services provided by Polish hauliers. European Journal of Service Management, 1 (25), 141-148. DOI: 10.18276/ejsm.2018.25-17. 